\title{
THE QUALITY OF VISUM ET REPERTUM ON THE INJURIES OF LIVING VICTIMS IN F. L. TOBING GENERAL HOSPITAL SIBOLGA AT 2018
}

\author{
Oktafianna Malau ${ }^{\mathrm{a}}$, Amri Amir $^{\mathrm{b}}$, Ismurizzal $^{\mathrm{c}}$ \\ Department of Forensic and Medicolegal of Faculty of Medicine Universitas Sumatera Utara, RSUP. H \\ Adam Malik j1. Bunga Lau no 17 Medan, Indonesia
}

Corresponding author’s e-mail: malauokta@gmail.com

\begin{abstract}
Visum et Repertum is a written statement made by a doctor, at the request of an investigator together with the authority to contain the results of medical examinations of humans, including living or dead victims. So far, no research has been conducted on the quality of Visum et Repertum for injuries at the General Hospital (RSU) of Dr. F. L. Tobing, Sibolga. The formulation of the problem in this study is "What is the quality of Visum et Repertum of live victims of injury cases at RSU Dr. F. L. Tobing Sibolga in 2018". This study is a descriptive study with a cross sectional approach. The population in this study were all Visum et Repetum data at dr. F. L. Tobing Sibolga in 2018. The research sample was obtained by using total sampling method. Visum et Repertum collected, recorded and tabulated with the type of variable to be examined based on Herkutanto scoring. Based on the results of this study, it was obtained: The number of wounded cases with live victims examined by doctors in charge of the emergency department was 62 cases. The quality of the Visum et Repertum for the injured victims in the introduction is $100 \%$ which means good quality, in the News section is $33 \%$ which means medium quality, in the conclusion is $50 \%$, which means that the quality is medium. And the quality of Visum et Repertum injuries to live victims was $59.2 \%$, which means that it was of moderate quality. Based on the results of this study, It is suggested that the RSU Dr. F.L. Tobing, Sibolga make standards and guidances in making Visum et Repertum, especially Visum et Repertum for live victims of injury cases that meet good Visum et Repertum standards.
\end{abstract}

Keywords: Visum et Repertum, Quality, Injury cases

\section{Introduction}

Living humans are required to have relationships with one another, cooperate, help to produce life. However, the interests of these interests are different and even conflict, so that it can lead to conflicts that disturb the harmony of life together, resulting in acts of violence against others. $[10,11]$

Based on data from the Central Statistics Agency (BPS), during the period 2016-2018 the number of crimes or criminal acts in Indonesia tended to fluctuate. The number of total crime incidents (crime total) nationwide in 2016 was 357,197 incidents, in 2017 there were 336,652 incidents and in 2018 there were 294,281 incidents.

For fair law enforcement, the state prepares legal instruments which for criminal cases are carried out in three stages, namely investigation, prosecution and termination of cases in court proceedings. Efforts made by law enforcement officers to find the material truth of a criminal case are confirmed in KUHAP Article 1 paragraph 2 concerning investigation.[9] 
And because law enforcement officials do not understand all the relation to violence against humans, a doctor's assistance is needed for the examination as outlined in a letter, which in KUHAP article 184 is a valid evidence. And this is regulated in Article 133 of the Criminal Procedure Code, namely that investigators have the authority to request medical assistance

Visum et Repertum is made for the benefit of law enforcement and justice, so that the quality and clarity of a Visum et Repertum made by a doctor greatly influences the clarity of a criminal case that occurs in relation to the body, health and human life. 3 Based on the results of several previous studies related to quality Visum et Repertum like Herkutanto's research in his 1999-2000 study of 977 VeR of living victims in 38 hospitals in Jakarta, it appears that most of the VeRs in various hospitals are still of low quality (Herkutanto, 2005) .[3]

So far, no research has been conducted on the quality of Visum et Repertum for injuries at Dr. F. L. Tobing Sibolga Hospital. Based on the background description, the authors are interested in knowing how the quality of Visum et Repertum victims of live injuries in the Dr. F. L. Tobing Sibolga Hospital in 2018.

Visum et Repertum is a statement made by a doctor at the request of an authorized investigator regarding the results of medical examinations of humans, whether alive or dead or parts of the human body, based on their knowledge and under oath, for the benefit of justice. (Budiyanto A, Widiatmaka W, Sudiono S, 1997) [2,8]

The legal basis of Visum et Repertum in the Criminal Procedure Code (KUHAP)

\section{KUHAP Article 133}

2. KUHAP Article 186

3. KUHAP Article 187 (c)

\section{KUHAP Article 184}

\section{Staatsblad (State Gazette) Year 1937 no. 350}

Visum et Repertum can play a role in the process of proving a criminal case against the health of the body and soul of humans, where Visum et Repertum describes everything about the 
examination of medical results contained in the news section which is considered as a substitute for evidence.

The contents of the Visum et Repertum consist of 5 basic frameworks consisting of:

\section{Pro Justitia}

The writing of the word "Pro Justitia" at the top left of Visum et Repertum which means for the sake of justice (Pro Justitia). The provisions for a stamp duty are in accordance with the provisions of UURI No. 13/2005 concerning Stamp Duty (adoption. Stamp duty 1921 article 23) all official letters for court cases must be stamped on paper or with the words "Pro Justitia". 31

\section{Introduction}

The introduction contains:

a. The identity of the applicant for Visum et Repertum.

b. The identity of the victim

c. The identity of the doctor who examined / made the Visum et Repertum.

d. Date and time of receipt of the application for Visum et Repertum.

e. Date and time of examination.

f. Place for inspection.

\section{News or results of examination}

The most important part of the post mortem actually lies in this section, where the doctor reports the results of his examination objectively according to what is observed especially seen and found on the victim or object being examined. The inspection is carried out systematically from top to bottom so that nothing is left out.

\section{Conclusion}

Contains the results of interpretations that can be scientifically justified from the facts found by the doctor who made the Visum et Repertum, related to the aims and objectives of requesting the 
Visum et Repertum. This section must contain at least 2 elements, namely the type of wound and violence and the degree of qualification of the wound. As well as the cause-and-effect relationship of the disorder, how long the victim is treated and how is the hope for a cure.

\section{Closing}

This section reminds the makers and users of Visum et Repertum that the report is made honestly and remembers any oaths or promises before carrying out an examination.

\section{Research Method}

This research is a descriptive research with a cross sectional approach, conducted at Dr. F. L. Tobing Sibolga Hospital, which is located at Jalan F.L Tobing No. 35 Municipality of Sibolga, Prov. North Sumatra, conducted from June 2020 to July 2020. The population in this study were all Visum et Repetum data at dr. FL Tobing Sibolga in 2018. The sample in this study is all Visum et Repetum data for live victims of injury cases that meet the inclusion criteria, namely Visum et Repertum data for live victims of injury cases and exclusion criteria, namely Visum et Repertum data for dead victims and Visum et Repertum data. rape victims at Dr. FL Tobing Sibolga Hospital in 2018 with the sampling technique using the total sampling method. The variables studied were various types of Visum et Repertum in live victims of injury cases.

\section{Result and Discussion}

Based on research on 5 - 13 July 2020 which was carried out at the Hospital Medical Record Installation. F. L. Tobing Sibolga, obtained the number of cases of injury with living victims as evidenced by the document Visum et Repertum during the period 01 January to 31 December 2018 , there were 62 cases.

1. Quality of Visum et Repertum of live victims of injury cases, introduction section

Quality of Visum et Repertum of live victims of injury cases in the preliminary section of the hospital. F. L. Tobing Sibolga from 01 January to 31 December 2018 is presented in table 1.

Table 1. Quality of Visum et Repertum of live victims of injury cases in the preliminary section of the hospital. F. L. Tobing Sibolga from 01 January to 31 December 2018. 


\begin{tabular}{llc}
\hline Structure of the VeR & Elements that are assessed & Mean Score \\
\hline Part & Checkpoint & 2 \\
Preliminary & Time of inspection & 2 \\
& Subject data & 2 \\
& Inspection Request Data & 2 \\
& Examining doctor data & \\
\hline
\end{tabular}

Average total score

Variable Group Introduction Part $=(2+2+2+2+2) \times 1=2$

Quality value of the introductory part $=\underline{(2 \times 1) \times 100 \%}=100 \%$

2. Quality of Visum et Repertum of live victims of injury cases in the reporting section

Quality of Visum et Repertum of live victims of injury cases in the news section of RSU. F. L. Tobing Sibolga from 01 January to 31 December 2018 is presented in table 2.

Table 2. Quality of Visum et Repertum of live victims of injury cases in the coverage section of the RSU. F. L. Tobing Sibolga from 01 January to 31 December 2018.

\begin{tabular}{llc}
\hline Structure of the VeR & Elements that are assessed & Mean Score \\
\hline Part & History & 0 \\
Preaching & Vital Sign & 2 \\
& Wound Characteristics & 2 \\
& Wound size & 2 \\
& Medicine and Care & 0 \\
\hline Average total score & & 3.3 \\
\hline
\end{tabular}

Group of Variable News Section $=\underline{0+2+2+2+2+0} \times 5=6,6$

6

The value of the quality of the news section $=(\underline{6,6 \times 5}) \times 100 \%=33 \%$ 


\section{Quality of Visum et Repertum of survivors of injury cases, conclusion}

Quality of Visum et Repertum of survivors of injury cases, the conclusion of the hospital. F. L. Tobing Sibolga from 01 January to 31 December 2018 is presented in table 3.

Table 3. Quality of Visum et Repertum of live victims of injury cases in the conclusion section at RSU. F. L. Tobing Sibolga from 01 January to 31 December 2018.

\begin{tabular}{llc}
\hline Structure of VER & Elements that are assessed & Mean Score \\
\hline Part Conclusion & Types of injuries and violence & 2 \\
& Wound qualification & 0 \\
\hline Average total score & & 1 \\
\hline
\end{tabular}

Group of Variable conclusion section $=\underline{0+2+2+2+2+0} \times 5=6,6$

6

The value of the quality of the conclusions section $=\left(\frac{6,6 \times 5}{10}\right) \times 100 \%=33 \%$

4. Quality of Visum et Repertum of live victims of injury cases in RSU. F. L. Tobing Sibolga in 2018

Quality of Visum et Repertum of live victims of wounded cases in RSU. F. L. Tobing Sibolga on January 1, 2018 to December 31, 2018 is presented in table 4.

Table 4. Quality of Visum et Repertum of live victims of injury cases in RSU. F. L. Tobing Sibolga from 01 January to 31 December 2018.

\begin{tabular}{lllll}
\hline \multicolumn{1}{c}{ Structure of VeR } & Mean Score & Value & Mean Score \\
\hline Part Preliminary & 2 & 1 & 2 & \\
Part Preaching & 0.66 & 5 & 3.3 & \\
Part Conclusion & 0,5 & 8 & 4 & 6,6 \\
\hline Total Score & & & &
\end{tabular}

Value of the quality of the life victim injury case visum $=$

$=(\underline{2+3,3+4}) \times 100 \%=59,2 \%$ 
Based on the results of this study conducted on Visum et Repertum, live victims of injury cases at the hospital. F. L. Tobing Sibolga on January 1 to December 31 2018, the quality of the Visum et Repertum of survivors of injury cases was $59.2 \%$, which means that of moderate quality.

From this research that the writing of Visum et Repertum of live victims of injury cases in RSU. F. L. Tobing Sibolga is still standard. Of the three sections of the Visum et Repertum, only the introductory section received good quality, while the news and conclusions section received moderate quality.

\section{Conclusion}

Based on the research results obtained from Visum et Repertum data on live victims of injury cases at the hospital. F. L. Tobing Sibolga on January 1, 2018 to December 31, 2018, it can be concluded:

a. Number of wounded cases with live victims examined by doctors on duty in the IGD (Emergency Room) at the Hospital. F. L. Tobing Sibolga, from January 1 to December 312018 , there were 62 cases.

b. Quality of Visum et Repertum of live victims of wounded cases in RSU. F. L. Tobing Sibolga from 01 January to 31 December 2018 the Introduction section is $100 \%$ which means good quality.

c. Quality of Visum et Repertum of live victims of wounded cases in RSU. F. L. Tobing Sibolga on January 1 to December 31, 2018, the news share was 33\%, which means that of medium quality.

d. Quality of Visum et Repertum of survivors of injury cases in RSU. F. L. Tobing Sibolga on January 1 to December 31, 2018 the conclusion is 50\% which means medium quality.

e. Quality of Visum et Repertum of survivors of injury cases in RSU. F. L. Tobing Sibolga from 01 January to 31 December 2018, the quality of Visum et Repertum was $59.2 \%$, which means that it was of medium quality.

Based on the quality of the Visum et Repertum, live victims of injury cases at the hospital. F. L. Tobing Sibolga period 01 January to 31 December 2018 with 62 samples obtained moderate results. This result is in line with the research of Intan Rosaline Simangunsong which showed that the quality of Visum et Repertum of live victims of injury 
cases at Siak Hospital for the period of January 1, 2009-31 December 2013 was 52.97\% which was categorized as moderate.

\section{REFERENCES}

[1] Amir Amri, Ilmu kedokteran Forensik Edisi kedua Tahun 2005, Hal:204-215

[2] Budiyanto Arif dkk, Ilmu Kedokteran Forensik, Edisi pertama, Cetakan kedua, UI, Jakarta, 1997. Hal:5-16.

[3] Hamdani Njowito, Ilmu Kedokteran kehakiman.Edisi kedua, Jakarta, PT Gramedia Pustaka Utama, 1992. Hal:21-30.

[4] Budiyanto A, Widiatmaka W, Sudiono S. Ilmu Kedokteran Forensik. Jakarta:Bagian Kedokteran Forensik Fakultas Kedokteran Universitas Indonesia. 1997.

[5] Dedi Afandi, Tata Laksana dan Teknik Pembuatan Visum et Repertum, Fakultas Kedokteran Universitas Riau. 2017

[6] Peningkatan Kualitas Pembuatan Visum et Repertum perlukaan pada korban hidup. Disampaikan pada Kongres Nasional Persatuan Dokter Forensik Indonesia. Ciawi, 1997

[7] Afandi D. Visum et Repertum pada korban hidup. Jurnal Ilmu Kedokteran. 2009;3(2):79-84.

[8] Herkutanto. Peningkatan Kualitas Pembuatan Visum et Repertum (VeR) kecederaan di rumah sakit melalui pelatihan dokter Unit Gawat Darurat (UGD). JPMK. 2005;8(3):163-9.

[9] KUHAP dan KUHP, Sinar Grafika, Jakarta,1998

[10] Pratiwi WS, Afandi D, Masdar H. Gambaran Visum et Repertum Perlukaan di Rumah Sakit Umum Daerah Kuantan Singingi periode 1 Januari 2009 - 31 Desember 2013. Journal FK Volume 2 No. 1 Februari 2015

[11] Wiraagni AI, Widihartono E. Karakteristik Kasus pada Visum et Repertum di RSUP dr. Soeradji Tirtonegoro Klaten 2014-2016. Vol.6, No.2, November 2016, Hal. 163-170

[12] Astuti NW. Analisis tingkat kriminalitas di Kota Semarang dengan pendekatan ekonomi tahun 2010-2012 [skripsi]. Semarang: Fakultas Ekonomi dan Bisnis Universitas Diponegoro; 2014.

[13] http://hukumtertulis.blogspot.com/penjelasan pasal-pasal

[14] http://belajarkedokteran45.blogspot.com/2015/12/visum-et-repertum-siapa-yang-berhakdan.html 
[15] Murtika IK., Prakoso D. Dasar-dasar ilmu kedokteran kehakiman. Cetakan ke-2. 1992. p $110-112$

[16] Dahlan S. Ilmu kedokteran Forensik. Cetakan III. Penerbit Universitas Diponegoro. Semarang. 2004: 177-182.

[17] https://dediafandi.staff.unri.ac.id/files/2010/05/Visum-et-Repertum-pada-korbanhidup.pdf

[18] https://media.neliti.com/media/publications/12542-ID-visum-et-repertum-pada-tahappenyidikan-dalammengungkap-tindak-pidana-pemerkosaa.pdf

[19] http://badiklat.kejaksaan.go.id/eakademik/uploads/modul/0648298f903bfdfed2e0677366080bf5.pdf

[20] https://media.neliti.com/media/publications/43243-ID-peranan-dokter-forensik-dalampembuktian-perkara-pidana.pdf

[21] https://luk.staff.ugm.ac.id/atur/UU29-2004PraktikKedokteran.pdf

[22] Budiyanto Arif dkk,Ilmu Kedokteran Forensik,Edisi pertama,Cetakan kedua,UI,Jakarta,1997.Hal:5-16.

[23] https://www.bps.go.id/publication/2019/12/12/66c0114edb7517a33063871f/statistikkriminal-2019.html

[24] Petrus A. Bahan ajar magister Kedokteran Klinis (MKK) forensik 2. USU Press. Medan, 2019.

[25] https://ejurnal.stikesmhk.ac.id/index.php/rm/article/viewFile/31/27

[26] http://riset.unisma.ac.id/index.php/jdh/article/download/3516/3171

[27] Notoadmodjo, S, 2010. Metodologi Penelitian Kesehatan. Jakarta: Rineka Cipta.

[28] http://fk.unri.ac.id/wp-content/uploads/2017/11/VeR-perlukaan-2010.pdf

[29] https://sibolgakota.bps.go.id/statictable/2016/07/28/89/banyaknya-peristiwa-kejahatanpelanggaran-yang-dilaporkan-dan-diselesaikan-menurut-jenis-kejahatan-di-kota-sibolga2015

[30] https://www.neliti.com/publications/186591/kualitas-visum-et-repertum-perlukaan-dirumah-sakit-umum-daerah-siak-periode- $1-\mathrm{j}$

[31] https://jdih.kemenkeu.go.id/fullText/1985/13TAHUN 1985UU.HTM 